\title{
Pronunciation Teaching: Past and Present
}

\author{
Saeed Ketabi \\ Faculty of Foreign Languages, University of Isfahan, Isfahan, Iran \\ Fateme Saeb (Corresponding author) \\ Faculty of Foreign Languages, University of Isfahan, Isfahan, Iran \\ E-mail: f.saeb1384@gmail.com
}

Received: 10-02- 2015

Published: 01-09- 2015
Accepted: 18-04- 2015

doi:10.7575/aiac.ijalel.v.4n.5p.182 URL: http://dx.doi.org/10.7575/aiac.ijalel.v.4n.5p.182
Advance Access Published: May 2015

\begin{abstract}
Pronunciation, despite being known as an important component of language learning, has not been awarded due attention within the field of language education. This article is a humble attempt to present an overview of the history of pronunciation teaching. Different approaches and methods of language teaching from the late nineteenth century into the new millennium are reviewed and discussed with regard to their stance in pronunciation instruction. Recent trends and issues of pronunciation teaching, e.g. intelligibility and Lingua Franca Core are also highlighted. Discussions like the present one might be beneficial in gaining a better understanding and evaluation of the status quo in order to improve and enhance the status of pronunciation instruction within language pedagogy.
\end{abstract}

Keywords: Pronunciation instruction, Teaching methods, Intelligibility, Lingua Franca Core

\section{Introduction}

Any discussion about pronunciation teaching and research is likely to begin with an acknowledgement of its being marginalized and neglected within the profession of English language teaching. Pronunciation has been referred to, in the literature, as "the Cinderella area of foreign language teaching" (Kelly, 1969), "the neglected orphan of second language acquisition studies" (Deng, Holtby, Howden-Weaver, Nessim, Nicholas, Nickle, Pannekoek, Stephan, \& Sun, 2009), "the poor relation of the English language teaching world" (Pardo, 2004) and "the lost ring of the chain" (Moghaddam, Nasiri, Zarea and Sepehrinia, 2012). Few practitioners involved in pronunciation teaching and pronunciation research would consider these titles as misnomers. According to Derwing (2010) pronunciation is an element of language which is granted little weight, if not completely discounted, by the teacher in the classroom and it seems that "L2 teachers are somewhat intimidated by the idea of teaching pronunciation" (p. 24). The importance of pronunciation, however, is critical enough to merit a far more serious attention from second language teachers and researchers alike, as it is a key to intelligible speech and effective communication in a globalized world.

Pronunciation has constantly changed position as various methods of language teaching have come and gone. It has been either elevated to the highest stature by some methods and approaches, such as the Reform Movement, Audiolingual method and Oral Approach, or has been assigned the back seat in the language classroom, as has been the case with Grammar-Translation Method, the Direct method, and the naturalistic approaches.

We will try in this paper to offer a summary review of the changing patterns and perspectives in the teaching of the pronunciation component over time. Major methods and approaches of language teaching will be reviewed in a chronological order with respect to their stance in pronunciation instruction. Finally, current issues and instructional strands in pronunciation teaching will be discussed.

\section{The 1800s and early 1900s: The Direct Method and the Reform Movement}

Pronunciation in this period was approached through an intuitive-imitative way (Celce-Murcia, Brinton \& Goodwin, 1996) in which the learner is supposed to listen and imitate the rhythm and sound system of the target language. There is no explicit information or instruction on how to pronounce the sounds. This is the approach to pronunciation teaching adopted by the Direct method which was first proposed in the late 1800s and gained popularity in the early 1900s. It was a reaction to the deficiencies inherent in the Grammar-Translation Method which taught language through detailed grammatical analysis and memorization of word lists. The Direct method was based on the assumption that a foreign language can be learnt in much the same way as a child acquiring her first language. Proponents of this method maintained that after a period of listening and internalization of the target sound system, learners would be able to "pick up" pronunciation without having received any explicit instruction.

In sharp contrast to the Direct Method, pronunciation in the Reform Movement gained great momentum. In 1890s phonetics was established as a scientific discipline by Henry Sweet, Wilhelm Vietor, and Paul Passy (Richards \& Rodgers, 2001) who influenced the development of the Reform Movement. Speech was recognized as the primary focus 
in language teaching. The International Phonetic Association was formed in 1886, and subsequently International Phonetic Alphabet (IPA) was devised. Phonetic training was utilized in this period as a tool for developing good pronunciation habits. During the prevalence of the Reform Movement lasting well into the second half of the twentieth century (Setter, 2006), pronunciation was deemed a major concern in second language instruction.

\section{The 1940s and 1950s: Audiolingual Method and Oral Approach}

Pronunciation continued to be in the forefront of the instructional agenda in the language classroom in 1940s and 1950s during the currency of the Audiolingual Method in the United States and Oral Approach and Situational Language teaching in Britain. Being influenced by the tenets of the Reform Movement, both methods allocated strong emphasis to pronunciation and start teaching it explicitly from the very first lesson. Accuracy was supported rather than fluency and the target sound system was practiced through pattern drills, mimicry, repetition, and the elimination of aberrant native language influences. Items for teaching pronunciation were presented in isolation using decontextualized practice of minimal pairs with a considerable emphasis on segmentals and individual sounds (Isaacs, 2009). Features of pronunciation such as phonemes and their meaningful contrasts, environmental allophonic variations, and combinatory phonotactic rules were specifically highlighted in the curriculum (Morley, 1991).

\section{The 1960s and 1970s: Loss of Favour}

These two decades are marked in the pronunciation teaching literature by a falling from grace. This decline was partly due to the introduction of the Cognitive Approach (Celce-Murcia et al., 1996; Levis, 2005) in the 1960s which led to the downfall of the audiolingualism. Cognitive approach was backed by Chomsky's revolutionary theory of transformational grammar which focused on the mental properties people bring into language use and language learning and regarded language as rule-governed system and not habit formation. This approach advocated a conscious focus on grammar and vocabulary and encouraged learners to use their innate and creative abilities to extract the underlying grammatical rules of the language (Richards \& Rodgers, 2001). In line with these assumptions, pronunciation teaching was abandoned and left to the learners' intuition.

Other approaches and methods which deemphasized pronunciation teaching in this period include the comprehensionbased approaches such as the Natural Approach and the Total Physical Response, and Suggestopedia (Pennington \& Richards, 1986; Celce-Murcia, 2013). Comprehension-based approaches to language teaching were based on the assumption that second language learning takes place in a process much like first language acquisition. Listening comprehension is granted the major importance and is considered the fundamental skill which can cause other skills and sub-skills to evolve automatically. According to this view, direct teaching of pronunciation is not supported since it is believed that learners will develop satisfactory pronunciation over time given the right conditions. Suggestopedia, as another of the designer methods of the 1970s, though presenting instructional material through reading long dialogues accompanied by classical music, does not address pronunciation explicitly and in later stages of learning, communication is emphasized at the expense of grammar and pronunciation (Richards \& Rodgers, 2001).

During these two decades, serious questions were raised by a number of researchers about the effectiveness of pronunciation teaching and whether any time should be devoted treating pronunciation in language classes. Some research findings signified the uselessness of pronunciation instruction and proposed that "little relationship exists between teaching pronunciation in the classroom and attained proficiency in pronunciation" (Suter, 1976; Suter \& Purcell, 1980, cited in Otlowski, 1998).

Another reason for the weakening of the position of pronunciation in this period was the arrival of the Communicative Language Teaching (CLT) in the late 1970s (Couper, 2008; Foote, Holtby \& Derwing, 2011; Isaacs, 2009; Lazaro Ibarrola, 2011; Morley, 1991). Early CLT in 1980s discounted pronunciation regarding it as a difficult feature, based on the assumption that teaching pronunciation would interfere communicative practice, and would be harmful to the students' self-confidence (Binte Habib, 2013). CLT proponents regarded pronunciation as part of the linguistic rather than communicative competence (Pennington \& Richards, 1986). Also, they assumed that input alone accompanied with no explicit instruction can improve learners' pronunciation. The focus on accuracy was replaced with an emphasis on fluency which led to the pronunciation being downplayed as teachers believed that the meaningless drills were not consistent with a communicative philosophy of language. As a result, pronunciation was generally disregarded or totally dropped from communicative instruction. CLT was not successful in providing teachers with adequate strategies for teaching pronunciation communicatively (Isaacs, 2009).

In more recent stages of its development, however, communicative approach changed its position with respect to pronunciation teaching (Foote et al., 2011; Couper, 2008). Research within the communicative paradigm demonstrated that pronunciation is an essential element of communicative competence which is the primary goal in CLT and that pronunciation should be given proper attention in the classroom. Ultimately it was revealed that the very inherent nature of the communicative approaches involves teaching pronunciation (Jenkins, 2004).

Finally, Morley, in his seminal paper on pronunciation component (1991), describes some of the underlying reasons for the decline of pronunciation in 1970s: "The elimination or reduction of the pronunciation component developed amid growing dissatisfaction with many of the principles and practices of the traditional approach to pronunciation. Factors involved included changing models of second language learning, changing foci in second language teaching, and changing models of linguistic description. New pedagogical sights were set on language functions, communicative competencies, task-based methodologies, and realism and authenticity in learning activities and materials." (p. 485). 
Though the 1970s is known as an era of fading into oblivion for pronunciation teaching, there is one method of language teaching in which pronunciation constitutes a genuine concern: the Silent Way. It emphasized the accuracy of the target language pronunciation and structure from the start. The teacher, as the name of the method implies, guided the students on how to pronounce words through gestures and tried to rely less on speaking. The Silent Way made use of a set of tools for the teaching of pronunciation such as sound-colour charts, the Fidel chart, and coloured Cuisenaire rods. All words were presented in wall charts and each letter had a different colour code to offer a visual illustration of the correspondences between sound and spelling. The advocates claimed that the method had great potentials in developing excellent pronunciation in learners (Richards \& Rodgers, 2001).

\section{The 1980s: The Revival}

During the last years of the 1970s there were signs of calling pronunciation back into the language curriculum. Some scholars put forward new insights and perspectives on pronunciation teaching, issues which had not been hitherto a concern of teachers and researchers, for example the importance of meaning and contextualized practice, learner involvement, self-monitoring, and learners' feelings, issues of intelligibility, variability and correction, and attention to stress, rhythm and intonation (Allen, 1971; Bowen, 1972; Dickerson, 1975; Morley, 1975; Olsen, 1976 cited in Morley, 1991). The raising of such issues and views instigated a renewed interest in pronunciation among teachers and researcher. Consequently, early 1980s witnessed a significant increase in the number of journal articles, reference books and materials dealing with pronunciation.

Increased awareness of the critical role of pronunciation in communication and the revived professional engagement in teaching it during the mid-1980s clearly indicated, as Morley (1991) aptly put it, "a persistent, if small, groundswell of movement to write pronunciation back into the instructional equation but with a new look and a basic premise: Intelligible pronunciation is an essential component of communicative competence." ( $\mathrm{p} .488$, emphasis in original). EFL teachers and researchers also admitted Morley's (ibid) admonishment that "ignoring students' pronunciation needs is an abrogation of professional responsibility".

As communicative approach flourished into its full bloom in 1980s resulting in an appreciation of pronunciation teaching and its importance among scholars and practitioners, and with the initiation of international communications and the formation of the "global civil society" (Castells, 2008, p. 78) after the cold war which further emphasized the value of comprehensible pronunciation, the first propositions of the intelligibility debate were advanced only to be fully discussed and exercised in the 1990s and into the new millennium.

\section{The 1990s and the New Millennium}

As obvious in the literature reviewed above, pronunciation experienced a constant fluctuation regarding its position in different language teaching methods and approaches. It has been exalted to the highest level of prominence by some approaches and methods as the Reform Movement and the Audiolingual Method, while relegated almost to the level of irrelevance by some others such as the Cognitive Approach. In contrast to this unpredictable and shifting pattern, however, the general position to pronunciation teaching has resisted change since the 1990s onwards. The interest in pronunciation teaching and research has continued to the extent that some of the prestigious journals in applied linguistics such as TESOL Quarterly and Prospect dedicated entire especial issues to pronunciation in the early 2000s. Among the most prominent issues and debates about pronunciation discussed and researched in this period are the intelligibility versus nativeness debate, segmentals/suprasegmentals controversy, and Jenkins' (2000) idea of Lingua Franca Core each of which are briefly reviewed in subsequent sections.

\subsection{Intelligibility versus Nativeness Debate}

Regarding the aim of pronunciation teaching, two conflicting principles have been supported: the nativeness principle and the intelligibility principle. The nativeness principle maintains that pronunciation teaching should be performed with the purpose of achieving a native-like mastery of the target sound system. Such was the aim of most pronunciation teaching programms until the 1960s. But it was called into question after the research findings indicated the existence of a critical period for learning pronunciation before adulthood, a hypothesis which proposed that the ability to acquire native-like pronunciation is biologically linked to age (Lenneberg, 1967, cited in Levis, 2005). This finding made achieving native-like pronunciation an unreasonable expectation of the learner (Levis, 2005).

Intelligibility principle, on the other hand, is a more realistic objective for pronunciation pedagogy. Munro and Derwing (1995) broadly define intelligibility as "the extent to which a speaker's message is actually understood by a listener" (p.75). This principle argues that gaining a native-like pronunciation is neither desirable nor possible for all learners and reaching a functional comprehensible speech is all foreign language learners need. Learners with an L1 accent can achieve fluency in L2 pronunciation as far as their accent does not impede intelligibility of their speech. Brown (2007) refers to this situation in his "Henry Kissinger effect" after the German U.S. secretary of state, an excellent example of poor pronunciation and very articulate and intelligible speech which positively surpassed that of many American nativespeakers.

The idea of intelligibility was suggested as a concern for pronunciation teachers and researchers long before the 1990s. Field (2005) cites Abercrombie's (1949: 120) remark: "Language learners need no more than a comfortably intelligible pronunciation". However, it took a few decades for it to influence the actual practice of language teachers in the classroom. In 2005 Field asserted that the most urgent issue in pronunciation research is identifying factors affecting learners' intelligibility. Several factors contributed to bringing intelligibility into the center of attention: the development and flourishing of communicative language teaching, the global spread of English as an international 
language and the coming forth of the notion of World Englishes, and the increase in the international communications for business, political and cultural purposes.

Even though communicative language teaching failed to spare proper attention to pronunciation in its initial stages of development as was discussed earlier, intelligible pronunciation was later identified as a vital constituent of communicative competence which lodges at the very heart of CLT. Communicative language teaching changed the instructional focus from the traditional, bottom-up approaches prioritizing accuracy and practicing isolated sounds to a more top-down approach concentrated on fluency and practicing suprasegmental features (Wach, 2012).

The passing of English as the international language reinforced the need to revisit the goals for pronunciation teaching. There was a consensus among scholars that in an age when English had adopted the role of the basic channel of international communication, native-like pronunciation seemed to be an unnecessary extravagance not every learner could afford. In view of this, Hinkel (2006) proposed three principled criteria for pronunciation teaching: (a) pronunciation and intonation should be taught in context and integrated with speaking skills, (b) pronunciation instruction should help wide-ranging communicative purposes, and (c) pronunciation and intonation should be taught based on realistic rather than idealistic language models.

The provision of the common tool for communication worldwide gave way to a rise in international communications among many nations which led to the fact that non-native speakers of English nowadays far outnumber its native speakers. Morley (1991) reported that the number of people in the world who use English is estimated to range from 750 million to a billion and a half. But only near 300 million of this population are native speakers. Also, Crystal (2012) estimated that approximately one fourth of the world's population are capable of communicating in English with only a small proportion of them being native speakers. These circumstances brought about new instructional demands and stressed the importance of intelligibility as the primary goal in pronunciation instruction. Jenkins (1998) stated: "Many of us working in the field of pronunciation have moved on from the position that deviation from the native norm is an error. We no longer regard English as being taught mainly for communication with its native speakers or the target of pronunciation teaching as a native-like accent. We acknowledge that the EFL-ESL distinction is beginning to blur as the two merge into English as an International Language" (p.119).

The major concern, at this point, for pronunciation specialists was to single out the features of natural speech which had the most contribution in intelligibility. This knowledge was important for deciding upon priorities and to design principled programs of instruction (Field, 2005). It was this concern for identifying contributive factors in intelligibility which paved the way for the segmentals/suprasegmentals controversy and the idea of Lingua Franca Core.

\subsection{Segmentals/Suprasegmentals Controversy}

Linguists have long been studying the importance of segmental and prosodic features in speech. Derwing (2010) cites Price (1665), concentrating mainly on the study of segmentals of English in his book The Vocal Organ, and Walker (1787) focusing on suprasegmentals. According to Celce-Murcia et al. (1996) until the 1970s pronunciation teaching was mostly dedicated to segmental features. However, with the advent of the communicative approach to language teaching in the late 1970s, most of the techniques and materials for treating segmental features were absolutely rejected since they were considered inconsistent with the tenets of CLT. Material developers and teachers decided, instead, that devoting time and resources to teaching suprasegmental features of language in a discourse context was the best way to manage a course in pronunciation for non-native speakers. As a result, suprasegmental features were at the center of attention of pronunciation teachers and researchers during 1990s and the early years of 2000s (Levis, 2005; Foote et al., 2011; Hahn, 2004; Field, 2005).

Yet, in 1990s voices were heard suggesting the importance of segmentals in achieving intelligibility. In an attempt to detect instructional priorities for enhancing intelligibility, researchers set out to determine whether one is more critical than the other. Bent, Bradlow and Smith (2006; cited in Zielinski, 2006), for example, studied the effect of deviant segments in different word positions on the intelligibility of sentences read aloud by L2 speakers from a Mandarin first language background. A score for intelligibility was given to each speaker. The basis for calculating scores was the percentage of key words correctly transcribed by five native (American) listeners. The intelligibility scores were then related to segments produced correctly in the sentences. The results revealed a significant correlation between intelligibility scores and segment production accuracy scores.

Other studies provided empirical support for the superiority of supresegmentals in attaining intelligibility. Hahn (2004) investigated native English speakers' understanding of nonnative primary stress in English sentences. She measured native speakers' processing, comprehension, and evaluations of three samples of a non-native speaker speech: with correct primary stress, incorrect primary stress, or totally missing. Results demonstrated that when listening to speech with correct primary stress, the participants recalled the content more easily and approved of the speaker's speech more than when primary stress was incorrect or missing. Her findings provided better understanding of how using a suprasegmental feature influences learners' intelligibility.

From the early years in the new millennium, pronunciation seemed to have moved on from the segmental/suprasegmental debate to a more balanced view acknowledging that the impairment of intelligibility can be associated with both segmental and suprasegmental features. At this point, pronunciation specialists were more concerned with what features to teach learners in a way to enable them to communicate most effectively, rather than to teach segmental or suprasegmental features (Couper, 2008; Levis, 2005; Moghaddam et al., 2012; Zeilinski, 2006). 


\subsection{Lingua Franca Core}

Central in the intelligibility principle is the assumption that different features have differential contribution to intelligibility and instruction should ideally pay primary attention to the features which affect understanding most and should give secondary importance to those features which are relatively less contributive to intelligibility. Field (2005) cites two scholars, Gimson (1978) and Jenner (1989) as pioneers in proposing a simplified phonological system for nonnative speakers. Jenkins (2000) extended their views suggesting a new international form of English which keeps most important features for intelligibility and restricts others that are of minor importance in this regard.

Taking conversations in English between non-native speakers (NNS) as data, Jenkins (2000) recognized key areas which need to be treated if communication was to be performed effectively and proposed them as a list. The aim of this list, which is known as the Lingua Franca Core (LFC), is to determine which features of English pronunciation make a difference in communication in international situations using English as a lingua franca. Jenkins insists that the LFC "is neither a pronunciation model nor a restricted simplified core" (2000: 158), rather, it introduces the features of English pronunciation which will make speakers from different first language backgrounds more intelligible to one another (Setter, 2006).

The idea of LFC provoked some controversy among researchers most of which were based on misunderstandings of the idea of English as a Lingua Franca (Kirkpatrick, 2010). Dauer (2005), for example, argued that LFC's de-emphasis on suprasegmentals will not suit learners well because the boundaries between English as a second language (ESL) and English as an international language (EIL) are not so clear-cut. Dziubalska-Kolaczyk (2005) also stressed the production/perception issue apparently discounted by LFC: Although learners are not expected to be able to produce certain sounds, they still need to understand them in order to communicate with native speakers (NS). Likewise, Sobkowiak (2005) stated that all the sounds of English are indispensable for NNS communication and we cannot make the language artificial and unnatural by limiting the sound system to "core" elements. Proponents of LFC, however, emphasized its concern for intelligibility, its value for international communication, and its learnability (Wach, 2012). Matsumoto (2011), for example, described the advantages of LFC in promoting negotiation among learners and providing a basis for an effective pronunciation syllabus. Despite the unresolved debate among researchers about the value of LFC, it continued to be one of the most influential ideas which emerged from the intelligibility principle in 2000s.

\section{Current Status}

As it was discussed above, pronunciation has been much neglected in the fields of language teaching and research. It has never regained the standing it enjoyed during the Reform Movement or the Audiolingual Method after the 1970s in spite of some rising and falling in status in different methods and approaches to language teaching. Thanks to the work of some dedicated researchers, however, pronunciation's rank has been promoted in language curriculum in the twentyfirst century. In 2004 Jenkins declared that "pronunciation has come of age and is unlikely to remain on the margins of language teaching in the 21 st century as it did for much of the final part of the twentieth" (p.120).

The call for pronunciation teaching has been partly answered by the release of several pronunciation textbooks and teachers' guides (Celce-Murcia et al., 2010; Grant, 2010; Yates \& Zielinski, 2009, among others). Also, there is currently a genuine interest in the use of technology in the teaching of pronunciation. One reason for that is the provision of a stress-free private condition for learners to access extensive input, practice at their own pace and receive immediate feedback (Hismanoglu, 2006) which in turn promotes learner autonomy. Some dictionary publishers, for example, are now issuing software with their dictionaries which provide the learner the opportunity to hear words both in isolation and in connected speech, and the possibility of recording their own voice and listening to it comparing their own pronunciation with that of the dictionary. Levis (2007), likewise, emphasizes the use of technology in diagnosing pronunciation errors.

Another improvement in the status of pronunciation in language teaching is the attempts made by language teachers and educators to integrate pronunciation with other language skills such as speaking and listening. This has been motivated in part by the global spread of English as the international language and the need for mutual intelligibility among speakers of many varieties of English (Moghaddam et al., 2012). Hinkel (2006: 116) expresses a similar view: "In an age of globalization, pragmatic objectives of language learning place an increased value on integrated multi-skill instructional models. Pronunciation therefore can be best taught in context and in conjunction with speaking skills".

In spite of the above mentioned advancements, the current stature of pronunciation instruction does not still correspond its importance and even now, in 2015, it seems not to be receiving due attention from teachers and practitioners in many language programs compared to other language skills and subskills (Kang, 2014; Murphy, 2014). A common finding among the studies focusing on pronunciation pedagogy has been a relative reluctance among teachers to teach pronunciation mostly as a result of lack of training in pronunciation instruction and access to appropriate materials (Foote, Holtby, \& Derwing, 2011; Thomson, 2013; Wahid \& Sulong, 2013).

From a theoretical point of view, some ideas and attitudes toward pronunciation teaching seem to be now taken for granted being the subject of broad consensus among researchers. These ideas include, inter alia, the primacy of intelligibility as the goal for pronunciation teaching, a balanced view of the importance of segmental and suprasegmental features in attaining intelligibility, and the need for a communicative instructional framework for teaching pronunciation. However, these theoretical axioms remain mainly in the form of theory and are yet to be considered seriously by the majority of instructors (Jenkins, 2006). 
In the contemporary field of language teaching, most teachers acknowledge that having a foreign accent is quite natural for EFL learners, and that pronunciation instruction should aim for intelligibility and comprehensibility. Nonetheless, there are still strong preferences among teachers and learners alike for native-like pronunciation models and little acknowledgment for non-native models in pronunciation teaching (He \& Zhang, 2010; Kopperoinen, 2011; Wach, 2012). Also, textbooks and resources for teaching pronunciation continue to massively represent minority prestigious accents such as the British Received Pronunciation or General American (Deterding, 2005; Levis, 2005).

Similarly, few researchers, if any, would argue the importance of integration of communicative features in pronunciation teaching. Celce-Murcia et al. (2010), for example, strongly urged developing communicative pronunciation teaching methods. Yet, the currently available materials for pronunciation teaching fall short of providing authentic, context-bound tasks to fulfill the requirements of a communicative approach. Apparently, teachers are less successful in filling the gap between pronunciation and communication than in other areas of language instruction. Isaacs (2009) believes that the existing situation is the result of the difficulties inherent in integrating pronunciation with communication. It is also the consequence of the long-existing elimination of pronunciation from the fields of language teaching and research.

\section{Final Words}

We live in a globalized world where English is no longer considered as a possession of its native speakers, but rather as a common tool for communication among many nations. Pronunciation as the primary component in oral communication is of great importance in this regard. We hope to have provided in this short piece a concise account of the journey of pronunciation since its departure from the intuitive-imitative approach gates in the nineteenth century until its arrival in the theoretically-accepted but not-yet-implemented emphasis on intelligibility in the second decade of the twenty-first century. Works such as the present one are attempts to review and evaluate the status quo in order to determine what we have fulfilled so far and what we have to fulfill in the future. This can help ultimately end the standing of pronunciation on the periphery of applied linguistics research and pedagogy and make the Cinderella analogy inapplicable to pronunciation.

\section{References}

Binte Habib, R. (2013). (Un) Intelligibility in EIL Pronunciation: An Analysis. IOSR Journal of Humanities and Social Science (IOSR-JHSS) 14, 21-26. http://dx.doi.org/10.9790/1959-1442126

Brown, H. D. (2007). Teaching by principles. White Plains, NY: Pearson.

Castells, M. (2008).The New Public Sphere: Global Civil Society, Communication Networks, and Global Governance. Annals AAPSS 616, 78-93. http://dx.doi.org/10.1177/0002716207311877.

Celce-Murcia, M. (2013). Language Teaching Methods from the Greeks to Gattegno. MEXTESOL Journal, 37, 1-9.

Celce-Murcia, M., Brinton, D.M., \& Goodwin, J.M. (1996). Teaching pronunciation: A reference for teachers of English to speakers of other languages. Cambridge, UK: Cambridge University Press.

Celce-Murcia, M., Brinton, D.M., Goodwin, J.M., \& Griner, B. (2010). Teaching pronunciation: A course book and reference guide (2nd ed.). New York: Cambridge University Press.

Couper, G. (2008). The short and long-term effects of pronunciation instruction. Prospect, 21, 46-66.

Crystal, D. (2012). English as a Global Language. Cambridge: Cambridge University Press. http://dx.doi.org/10.1017/CBO9781139196970

Dauer, R. (2005). The Lingua Franca Core: A new model for pronunciation instruction? TESOL Quarterly, 39, 543-550. http://dx.doi.org/10.2307/3588494

Deng, J., Holtby, A., Howden-Weaver, L., Nessim, L., Nicholas, B., Nickle, K., Pannekoek, C., Stephan, S., \& Sun, M. (2009). English pronunciation research: The neglected orphan of Utopian Goals | 35 Selected Papers from the 1st Annual Conference on Pronunciation in Second Language Learning and Teaching second language acquisition studies. Prairie Metropolis Centre Working Paper Series, WP05-09, Edmonton, AB.

Derwing, T. M. (2010). Utopian goals for pronunciation teaching. In J. Levis \& K. LeVelle (Eds.), Proceedings of the 1st Pronunciation in Second Language Learning and Teaching Conference, Iowa State University, Sept. 2009. (pp. 2437), Ames, IA: Iowa State University.

Deterding, D. (2005). Emergent patterns in the vowels of Singapore English. English World Wide 26, 179-197.

http://dx.doi.org/10.1075/eww.26.2.04det

Dziubalska-Kolaczyk K. (2005). Native or non-native? This is the question: Which English to teach in the globalizing world? In Proceedings of PTLC 2005 [CDROM]. London: Department of Phonetics and Linguistics, UCL.

Field, J. (2005). Intelligibility and the listener: The role of lexical stress. TESOL Quarterly 39, 399-423. http://dx.doi.org/10.2307/3588487

Foote, J.A., Holtby, A.K., \& Derwing, T.M. (2011). Survey of the teaching of pronunciation in adult ESL programs in Canada. TESL Canada Journal, 29, 1-22. 
Grant, L. (2010). Well said: Pronunciation for clear communication (3rd ed.). Boston, MA: Heinle \& Heinle.

Hahn, L. D. (2004). Primary stress and intelligibility: Research to motivate the teaching of suprasegmentals. TESOL Quarterly 38, 201-223. http://dx.doi.org/10.2307/3588378

He, D., \& Zhang, Q. (2010). Native speaker norms and China English: From the perspective of learners and teachers in China. TESOL Quarterly, 44, 769-789. http://dx.doi.org/10.5054/tq.2010.235995

Hinkel, E. (2006). Current perspectives on teaching the four skills. TESOL Quarterly, 40, 109-131.

http://dx.doi.org/10.2307/40264513

Hismanoglu, M. (2006). Current perspectives on pronunciation learning and teaching. Journal of Language and Linguistic Studies 2,101-110.

Isaacs, T. (2009). Integrating form and meaning in L2 pronunciation instruction. TESL Canada Journal, $27,1-12$.

Jenkins, J. (1998). Which pronunciation norms and models for English as an International Language? ELT Journal, 52 , 119-126. http://dx.doi.org/10.1093/elt/52.2.119

Jenkins, J. (2000). The phonology and English as an international language: new models, new norms, new goals. Oxford: Oxford University Press.

Jenkins, J. (2004). Research in teaching pronunciation and intonation. Annual Review of Applied Linguistics 24,109125. http://dx.doi.org/10.1017/S0267190504000054

Jenkins, J. (2006). Current perspectives on teaching World Englishes and English as a lingua franca. TESOL Quarterly 40, 157-181. http://dx.doi.org/10.2307/40264515

Kang, O. (2014). Learners' Perceptions Toward Pronunciation Instruction in Three Circles of World Englishes. TESOL Journal. DOI: 10.1002/tesj.146. http://dx.doi.org/10.1002/tesj.146

Kelly, L.G. (1969). 25 centuries of language teaching: An inquiry into the science, art, and development of language teaching methodology, 500 B.C.-1969. Rowley, MA: Newbury House.

Kirkpatrick, A. (2010). English as an Asian lingua franca and the multilingual model of ELT. Language Teaching, 44(2), 212-224. http://dx.doi.org/10.1017/S0261444810000145

Kopperoinen, A. (2011). Accents of English as a lingua franca: a study of Finnish textbooks. International Journal of Applied Linguistics, 21, 71-93. http://dx.doi.org/10.1111/j.1473-4192.2010.00263.x

Lazaro Ibarrola, A. (2011). Imitating English Oral Texts: A Useful Tool to Learn English Pronunciation? Porta Linguarum, 16, 49-63.

Levis, J. (2007). Computer technology in teaching and researching pronunciation. Annual Review of Applied Linguistics 27, 184-202. http://dx.doi.org/10.1017/S0267190508070098

Levis, J.M. (2005). Changing contexts and shifting paradigms in pronunciation teaching. TESOL Quarterly, 39, 369377. http://dx.doi.org/10.2307/3588485

Matsumoto, Y. (2011). Successful ELF communications and implications for ELT: Sequential analysis of ELF pronunciation negotiation strategies. Modern Language Journal, 95, 97-114. http://dx.doi.org/10.1111/j.15404781.2011.01172.x

Moghaddam, M., Nasiri, M., Zarea, A., \& Sepehrinia, S. (2012). Teaching Pronunciation: The Lost Ring of the Chain. Journal of Language Teaching and Research, 3, 215-219. http://dx.doi.org/10.4304/j1tr.3.1.215-219

Morley, J. (1991). The pronunciation component in teaching English to speakers of other languages. TESOL Quarterly, 25, 481-520. http://dx.doi.org/10.2307/3586981

Munro, M.J., \& Derwing, T.M. (1995). Foreign accent, comprehensibility, and intelligibility in the speech of second language learners. Language Learning, 45, 73-97. http://dx.doi.org/10.1111/j.1467-1770.1995.tb00963.x

Murphy, J.M. (2014). Intelligible, comprehensible, non-native models in ESL/EFL pronunciation teaching. System 42 , 258-269. http://dx.doi.org/10.1016/j.system.2013.12.007

Otlowski, M. (1998). Pronunciation: What are the expectations? The Internet TESL Journal, 4(1).

Pardo, D. B. (2004). Can pronunciation be taught? A review of research and implications for teaching. Revista Estudios Ingleses 17, 5-34.

Pennington, M.C., \& Richards, J.C. (1986). Pronunciation revisited. TESOL Quarterly, 20, 207-225.

http://dx.doi.org/10.2307/3586541

Richards, J., \& Rodgers, T. (2001). Approaches and methods in language teaching. Cambridge: Cambridge University Press.

http://dx.doi.org/10.1017/CBO9780511667305

Setter, J. (2006). Speech rhythm in world Englishes: The case of Hong Kong. TESOL Quarterly, 40, 763-782.

http://dx.doi.org/10.2307/40264307. 
Sobkowiak, W. (2005). Why not LFC? In K. Dziubalska-Kolaczyk \& J. Przedlacka (Eds.), English pronunciation models: A changing scene (pp. 131-149). Bern: Peter Lang.

Thomson, R. I. (2013). ESL teachers' beliefs and practices in pronunciation teaching: Confidently right or confidently wrong? In J. Levis \& K. LeVelle (Eds.). Proceedings of the 4th Pronunciation in Second Language Learning and Teaching Conference. Aug. 2012. (pp. 224-233). Ames, IA: Iowa State University.

Wach, A. (2012). Native-speaker and English as a lingua franca pronunciation norms: English majors' views. Studies in Second Language Learning and Teaching, 1, 247-266.

Wahid, R., \& Sulong, S. (2013). The Gap between Research and Practice in the Teaching of English Pronunciation: Insights from Teachers' Beliefs and Practices. World Applied Sciences Journal, 21, 133-142.

Yates, L., \& Zielinski, B. (2009). Give it a go: Teaching pronunciation to adults. Sydney, NSW: AMEP Research Centre.

Zielinski, B. (2006). The intelligibility cocktail: An interaction between speaker and listener ingredients. Prospect, 21, $22-45$. 